\title{
Methylosoma difficile gen. nov., sp. nov., a novel methanotroph enriched by gradient cultivation from littoral sediment of Lake Constance
}

\author{
Monali Rahalkar, Ingeborg Bussmann and Bernhard Schink \\ LS Mikrobielle Ökologie, Fachbereich Biologie, Universität Konstanz, Fach M 654, \\ 78457 Konstanz, Germany
} Correspondence
Bernhard Schink
bernhard.schink@uni-konstanz.de

\section{INTRODUCTION}

Aerobic methane-oxidizing bacteria (MOB) or methanotrophs are a unique and important group of bacteria which act as natural filters, controlling the release of methane, an important greenhouse gas, from anoxic sediments and soils. Aerobic MOB in freshwater environments such as lake sediments are active at the zone where methane and oxygen meet. In a previous study from our lab, a specific cultivation set-up was developed in which methanotrophic bacteria were grown in opposing gradients of methane and oxygen (Bussmann et al., 2006). A novel bacterial strain, LC $2^{\mathrm{T}}$, was isolated which was found to be moderately related to the Methylobacter-Methylosarcina group (92-94\% similarity) and less related to the other genera of MOB (similarity 90-91\%), e.g. Methylomonas and Methylomicrobium, as determined by $16 \mathrm{~S}$ rRNA gene sequence comparison. The closest relatives of this new strain were Methylobacter species such as Methylobacter psychrophilus (Tourova et al., 1999) and the recently described Methylobacter tundripaludum

Abbreviations: MOB, methane-oxidizing bacteria; sMMO, soluble methane monooxygenase.

The GenBank/EMBL/DDBJ accession numbers for the complete 16S rRNA gene sequence and partial pmoA and nifH gene sequences of strain LC $2^{\top}$ are respectively DQ119050, DQ1 19047 and DQ665842.
SV96 ${ }^{\mathrm{T}}$ (Wartiainen et al., 2006), which are either psychrophilic or have been isolated from cold habitats. In cultureindependent studies, we found that littoral sediment of Lake Constance is dominated by type I MOB (Bussmann et al., 2006; Pester et al., 2004). Among these, Methylobacter-like $\mathrm{MOB}$ (clone group B1) dominated clone libraries of the partial pmoA gene (Bussmann et al., 2006) amplified with primers A189f-A682r (Holmes et al., 1995) as well as with primers A189f-mb661r (Costello \& Lidstrom, 1999) and contributed to the major peaks observed in T-RFLP studies from the littoral sediment of Lake Constance (Pester et al., 2004). Recently, many pmoA and 16S rRNA gene sequences related to the genus Methylobacter have been reported as dominant groups in other freshwater habitats such as freshwater wetland marshes (Bodelier et al., 2005) and lakes such as Mono Lake (Lin et al., 2005) and Lake Washington (Nercessian et al., 2005), estuarine habitats (McDonald et al., 2005), as well as in chironomid larvae in lake sediments (Eller et al., 2005). To date, a total of 13 genera of methanotrophs have been described, which belong to either the class Alphaproteobacteria (type II MOB) or Gammaproteobacteria (type I MOB). Recently, it was discovered that Crenothrix polyspora Cohn, a well-known, uncultured filamentous bacterium, is a methane oxidizer, and its $16 \mathrm{~S}$ rRNA genes (total of four clusters) formed a new group within the family 
Methylococcaceae which also branched near Methylobacter psychrophilus and related methanotrophs (Stoecker et al., 2006).

The purpose of the present study is to characterize strain LC $2^{\mathrm{T}}$ formally and to determine its correct taxonomical position. Although this strain was isolated from a gradient culture, it could also grow on solid and in liquid media.

\section{METHODS}

Isolation and growth conditions. Strain $\mathrm{LC} 2^{\mathrm{T}}$ was isolated from littoral sediment of Lake Constance after an initial enrichment in a gradient culture followed by transfer into a liquid dilution series and finally on solid agarose medium, as described in detail by Bussmann et al. (2006). Cells were grown in dilute mineral medium (Bussmann et al., 2006) either in liquid medium, on solid medium (with $1.2 \%$ agarose NEEO, Ultraquality; Roth) with $0.01 \%$ cycloheximide or in a gradient system ( $0.2 \%$ agarose) with opposing gradients of methane and oxygen as described before (Bussmann et al., 2006). Growth on $1.5 \%$ agar (BD Biosciences) was also checked. The diluted medium as described in Bussmann et al. (2004) contained the following salts (per litre): $0.1 \mathrm{~g} \mathrm{NaCl}, 0.04 \mathrm{~g}$ $\mathrm{MgCl}_{2} .6 \mathrm{H}_{2} \mathrm{O}, 0.05 \mathrm{~g} \mathrm{KCl}, 0.015 \mathrm{~g} \mathrm{CaCl}_{2} .2 \mathrm{H}_{2} \mathrm{O}, 0.016 \mathrm{~g} \mathrm{Na}_{2} \mathrm{SO}_{4}$ and trace element solution SL $10\left(1 \mathrm{ml} \mathrm{l}^{-1}\right)$ (Widdel, 1988). Potassium/ sodium phosphate buffer ( $\mathrm{pH}$ 7.2) and $\mathrm{KNO}_{3}$ were added to final concentrations of $150 \mu \mathrm{M}$ and $50 \mu \mathrm{M}$, respectively, and the medium was buffered to $\mathrm{pH} 7.2$ with 0.01 M HEPES. In addition, a sevenvitamin solution (Widdel \& Pfennig, 1981) was added $\left(1 \mathrm{ml} \mathrm{l}^{-1}\right)$. Strain LC $2^{\mathrm{T}}$ was checked also for growth in: (i) classical nitrate mineral salt medium (Whittenbury et al., 1970) with the trace element solution replaced by SL 10 solution, (ii) low-nitrate mineral salt medium ( $1 / 10$ concentration of potassium nitrate, $\mathrm{pH} 7.0$ with HEPES buffer) and (iii) medium with 10 -fold-concentrated version of the above-mentioned mineral medium (Bussmann et al., 2004). The effect of copper on growth was checked by inoculating the culture with additional $1-5 \mu \mathrm{M} \mathrm{CuSO}_{4}$ in liquid medium. The basal concentration of copper in the mineral medium was very low $(0.011 \mu \mathrm{M})$. Strain LC $2^{\mathrm{T}}$ was grown in $100 \mathrm{ml}$ flasks or $15 \mathrm{ml}$ glass tubes with 25-30 or $5 \mathrm{ml}$ medium, respectively, in closed desiccators. The strain was maintained by streaking single colonies on solid agarose plates or by inoculating a single colony in liquid medium and then streaking the grown liquid culture on agarose plates. Until about a year after isolation, strain LC $2^{\mathrm{T}}$ was grown in closed desiccators under a gas atmosphere of $24 \%$ methane, $2 \% \mathrm{CO}_{2}, 17 \% \mathrm{O}_{2}$ and the balance $\mathrm{N}_{2}$ (Bussmann et al., 2006). As the strain grew well in gradients and appeared to grow at low oxygen tension (Bussmann et al., 2006), the gas atmosphere for growing this culture was modified slightly to $20 \%$ methane, $2 \% \mathrm{CO}_{2}, 30 \%$ air (around $6 \% \mathrm{O}_{2}$ ) and the balance $\mathrm{N}_{2}$. All growth experiments performed in this study were performed with this modified gas atmosphere in the dark at 16 or $21{ }^{\circ} \mathrm{C}$, unless otherwise mentioned. The strain was also tested for growth in closed $150 \mathrm{ml}$ bottles with different volumes of liquid medium and a gas phase of methane and air (20:80). Possible presence of heterotrophic contaminants was checked every time by plating on 1:10-diluted nutrient agar plates with an additional $0.05 \%$ yeast extract. For long-term storage, glycerol stocks were prepared and preserved at $-70{ }^{\circ} \mathrm{C}$. Survival of the strain after such preservation was checked by inoculation into fresh medium. Cultures were also preserved at $4{ }^{\circ} \mathrm{C}$ for long-term storage. Ten per cent inoculum was used in all growth experiments and the incubation period was 8 weeks. Since the bacteria tended to grow as a faint pink biofilm at the bottom, the tube or flask was shaken well to suspend the cells uniformly before the $\mathrm{OD}_{570}$ was recorded. Growth was always confirmed by phase-contrast microscopy.
Morphological characterization and electron microscopy. Cells were observed under a phase-contrast microscope (Axiophot; Zeiss) and photographed with a cooled charge-couple device camera (Magnafire; INTAS). For fixation for electron microscopy, $50 \mathrm{ml}$ of an exponentially growing culture was spun down at $5000 \mathrm{~g}$. The cell pellet was washed once with $\mathrm{PBS}(50 \mathrm{mM}$ potassium phosphate buffer, pH 7.5, plus $0.9 \% \mathrm{NaCl}$ ) and then suspended in $1 \mathrm{ml}$ PBS. Glutaraldehyde ( $140 \mu \mathrm{l}$ of a $25 \%$ aqueous solution) was added to the cell suspension, which was then incubated overnight at $4{ }^{\circ} \mathrm{C}$, before the cells were centrifuged again at $5000 \mathrm{~g}$. The pellet was washed again in PBS and finally suspended in around $150 \mu \mathrm{l}$ PBS. After chemical fixation, cells were embedded in $1.5 \%(\mathrm{w} / \mathrm{v})$ molten agar (final concentration). The agar block was cut into small pieces of $1 \mathrm{~mm}^{3}$ and the pieces were dehydrated in a graded methanol series (v/v: 15 and $30 \%$ for $15 \mathrm{~min} ; 50,75$ and $95 \%$ for $30 \mathrm{~min}$; $100 \%$ for $1 \mathrm{~h}$ ) under concomitant temperature reduction to $-40{ }^{\circ} \mathrm{C}$. The samples were infiltrated with Lowicryl $\mathrm{K} 4 \mathrm{M}$ resin [in methanol (v/v): $50 \%$ for $1 \mathrm{~h} ; 66 \%$ for $2 \mathrm{~h} ; 100 \%$ for $10 \mathrm{~h}$ ] and then polymerized for $24 \mathrm{~h}$ at $-40{ }^{\circ} \mathrm{C}$ and for 3 days at room temperature (Roth et al., 1981; Hoppert \& Holzenburg, 1998). Resin sections of 80$100 \mathrm{~nm}$ thickness were cut with glass knives. Electron microscopy was performed in a Philips EM 301 transmission electron microscope at $80 \mathrm{kV}$ with calibrated magnifications. To check for the presence of cellular appendages like flagella or pili, negative stainings were prepared with fresh cell material.

Utilizable carbon and nitrogen sources. Utilization of various carbon sources was studied in liquid mineral medium supplemented with one of the following filter-sterilized substrates $(0.1 \%$, w/v): formate, formamide, arabinose, raffinose, lactose, maltose, xylose, glucose, fructose and sucrose. The ability of the strain to grow on methanol and formaldehyde was tested at lower concentrations (10-50 mM methanol and $1-50 \mathrm{mM}$ formaldehyde). Other substrates such as acetate $(2$ and $10 \mathrm{mM})$ were tested for growth in liquid medium to check for heterotrophic growth (Dedysh et al., 2005) of strain LC $2^{\mathrm{T}}$. Nitrogen sources were tested with liquid medium in which $\mathrm{KNO}_{3}$ was replaced by one of the following compounds at $0.05 \%(\mathrm{w} / \mathrm{v}): \mathrm{NH}_{4} \mathrm{Cl}$, urea, glycine, serine, valine, asparagine, aspartate, L-glutamic acid, glutamate, peptone and yeast extract. To test the ability of the culture to fix atmospheric $\mathrm{N}_{2}$, media free of bound nitrogen compounds were used. The acetylene reduction test was done with cultures grown with $10 \mathrm{mM}$ methanol without any bound nitrogen source, as modified by Auman et al. (2001). Briefly, $25 \mathrm{ml}$ of such a grown culture was transferred to a bottle with a rubber stopper and was gassed with nitrogen; air and acetylene were added ( $89 \% \mathrm{~N}_{2}: 9 \%$ air: $1 \%$ acetylene) and incubated overnight. The gas phase was checked for ethylene production by gas chromatography.

Optimum pH, temperature and salt content. The optimum $\mathrm{pH}$ and temperature ranges were determined in liquid medium. Growth at $\mathrm{pH}$ 2.6-9.0 was checked after buffering the medium with citrate/ phosphate buffer ( $\mathrm{pH}$ 2.6-6.6), HEPES buffer ( $\mathrm{pH} 7$ and 7.5) and glycine buffer ( $\mathrm{pH} 8$ and 9). Growth was also checked without using any buffer, but using only $\mathrm{HCl}$ or $\mathrm{NaOH}$ to adjust the $\mathrm{pH}$. Strain LC $2^{\mathrm{T}}$ was grown at a temperature range of $4-37^{\circ} \mathrm{C}$ in liquid medium. To determine the optimum salt concentration, additional $\mathrm{NaCl}(0.5,1,1.5$ and $2.0 \%$, w/v) was added to the mineral medium. The basal $\mathrm{NaCl}$ concentration in the mineral medium was $0.01 \%$ $(\mathrm{w} / \mathrm{v})$.

Resistance to desiccation and heat. Heat resistance was tested by heating cell suspensions at $50,60,70$ or $80^{\circ} \mathrm{C}$ for 10 min each followed by plating onto solid medium and incubating under optimal conditions for 2-3 weeks. Desiccation resistance was assessed according to Whittenbury et al. (1970) by air-drying suspensions of strain LC $2^{\mathrm{T}}$ on glass slides and then inoculating into medium after an interval of 1-4 weeks. Formation of exospores was checked for 
by heating a 3-4 week old culture at $80{ }^{\circ} \mathrm{C}$ for $20 \mathrm{~min}$ and then looking for colony formation after incubation under standard conditions (Bowman et al., 1993). Cysts were stained according to Vela \& Wyss (1964).

Cellular fatty acid analysis. Phospholipid fatty acid analyses were performed at the Deutsche Sammlung von Mikroorganismen und Zellkulturen GmbH (DSMZ, Braunschweig, Germany). Strain LC $2^{\mathrm{T}}$ was grown in $200 \mathrm{ml}$ flasks, in closed desiccators. Cells were pelleted, freeze-dried and sent for phospholipid fatty acid analysis. There, the cells were saponified and methylated and the methyl esters were extracted and subjected to GC. The GC elution profile of the fatty acid methyl esters was compared with the fatty acid patterns stored in the fatty acid database of the Microbial Identification System (MIDI Inc.) and qualitative and quantitative compositions of the pattern were given.

Presence of soluble methane monooxygenase (sMMO) and nitrogenase. The presence of sMMO was checked by PCR amplification of the mmoX gene with primers mmoXA-mmoXB (Auman et al., 2000) as well as by colorimetric assay (Graham et al., 1992). To check for the presence of nitrogenase, the nifH gene was amplified as described by Poly et al. (2001), partially sequenced and subjected to BLAST search at the NCBI (http://www.ncbi.nlm.nih.gov/) (Altschul et al., 1990).

DNA extraction, phylogenetic analysis and $\mathrm{G}+\mathrm{C}$ content. DNA was extracted and the complete 16S rRNA gene sequence was determined as described previously (Bussmann et al., 2006). $16 \mathrm{~S}$ rRNA gene sequences of type I methanotrophs of the family Methylococcaceae along with newly described sequences of Crenothrix polyspora and sequences of some clones were obtained after BLAST search. Phylogenetic analysis was done using the ARB software package (version 2.5b) (http://www.arb-home.de; Ludwig et al., 2004). The new sequences were added to the ARB database and aligned using the FAST Aligner tool as implemented in ARB. Alignments were checked and corrected manually where necessary. Sequences of 1419 nucleotides were used for alignment. Only those positions that were identical in at least $50 \%$ of all sequences were used to create a filter. Phylogenetic analysis was done using the maximumlikelihood, neighbour-joining and maximum-parsimony algorithms as implemented in ARB (Ludwig et al., 2004). Phylogenetic distances were also determined by using the similarity matrix in ARB without using any filter and also with a sequence of Escherichia coli as the filter. Phylogenetic analysis of the pmoA gene was done as described earlier (Bussmann et al., 2006), and phylogenetic trees were constructed based on 164 amino acids. G $+\mathrm{C}$ content was measured at the DSMZ by HPLC by a method adapted from Tamaoka \& Komagata (1984) and calculated according to the method of Mesbah et al. (1989).

\section{RESULTS AND DISCUSSION}

\section{Isolation and growth characters of strain LC $\mathbf{2}^{\mathbf{T}}$}

Strain LC $2^{\mathrm{T}}$ was isolated after enrichment in a gradient culture system obtained after a final dilution of $8 \times 10^{-4}$ of the littoral sediment, after further transfers on liquid and solid media (Bussmann et al., 2006). The strain was isolated from a mixed culture in which it was associated with thin rods. When isolated, the colonies were much bigger and more mucoid and watery than after extended cultivation. This could be due to a tendency of the cells to form aggregates or to the presence of an initially contaminating bacterium. The strain grew in liquid culture at low oxygen tensions, up to $10 \%$ air, i.e. $2 \%$ oxygen. In gradients, it formed two bands, the deepest one being $32 \mathrm{~mm}$ from the air-exposed end (Bussmann et al., 2006). Strain LC $2^{\mathrm{T}}$ also grew well on $1.5 \%$ agar, although agarose was used routinely. The strain could not be maintained on solid medium by repeated transfers. Therefore, a single colony was always grown in liquid culture and then streaked on solid medium. No active motility could be detected 2 years after isolation. Cells occurred singly or in pairs or sometimes in chains of four or five cells (especially on solid medium) or in aggregates. In liquid medium, strain LC $2^{\mathrm{T}}$ formed a mucoid pink biofilm at the bottom of the flask. If the flask was shaken, a whorl of mucoid biofilm appeared which was held together at a small point in the centre of the flask. After shaking, the cells could be suspended uniformly. Cells also became oval or elliptical in shape and changed from coccoid to rod-shaped forms in older cultures. Liquid cultures grew better in magnetically stirred flasks inside a desiccator. Strain LC $2^{\mathrm{T}}$ resembled Methylobacter tundripaludum SV96 ${ }^{\mathrm{T}}$ in colony colour and cell size (Table 1). Comparison of strain LC $2^{\mathrm{T}}$ with members of other methanotrophic genera is shown in Table 1 .

Table 1. Comparison of strain $L C 2^{\top}$ with other methanotrophic genera

\begin{tabular}{|c|c|c|c|c|c|c|}
\hline Characteristic & Methylomonas & Methylomicrobium & Methylosarcina ${ }^{\star}$ & Methylosphaera & Methylobacter & Strain LC $2^{\mathrm{T}}$ \\
\hline Cyst formation & + & - & Variable & - & + & + \\
\hline Nitrogenase genes & Variable & - & - & + & + & + \\
\hline Pigmentation & $\begin{array}{c}\text { Pink, yellow- } \\
\text { ochre }\end{array}$ & White & $\begin{array}{l}\text { Light brown- } \\
\text { buff }\end{array}$ & - & $\begin{array}{l}\text { Yellow, brown } \\
\text { or pale pink } \dagger\end{array}$ & Pale pink \\
\hline $\mathrm{G}+\mathrm{C}$ content $(\mathrm{mol} \%)$ & $51-59$ & $50-60$ & $53-54$ & $43-46$ & 49-54 & 49.9 \\
\hline
\end{tabular}

${ }^{\star}$ Except Methylosarcina lacus.

$\uparrow$ Methylobacter tundripaludum. 
Strain LC $2^{\mathrm{T}}$ did not survive in glycerol stock cultures. After initial growth at optimum temperature, the strain survived well at $4{ }^{\circ} \mathrm{C}$ for $2-3$ months. Poor growth was observed at increased copper concentrations. The strain grew well in dilute nitrate mineral salt medium and undiluted mineral medium but grew poorly in the classical nitrate mineral salt medium. It also grew well in non-shaken closed bottles $(150 \mathrm{ml})$, with $15-20 \mathrm{ml}$ medium and $20 \%$ methane in the gas phase.

\section{Morphological characterization and electron microscopy}

Strain LC $2^{\mathrm{T}}$ formed pale-pink colonies, around 1-2 mm diameter on agarose plates and $2-3 \mathrm{~mm}$ diameter on agar, after incubation for 2-3 weeks (Table 1). Coccoid cells were observed (often in pairs) by phase-contrast microscopy which were $1.5-2 \mu \mathrm{m}$ in length and approximately $1 \mu \mathrm{m}$ in diameter (Fig. 1a). Intracytoplasmic membranes were arranged in stacks, mainly at the cell periphery (Fig. 1b), which is a feature typical of type I methanotrophs (Whittenbury et al., 1970). Cells contained large polyhydroxyalkanoate granules and, very probably, also glycogen granules, which stained dark.

Ultrathin sections of the cell periphery exhibited an appearance typical of a Gram-negative cell envelope, with two dark, thin layers of the outer membrane, a peptidoglycan layer located in the periplasm and a cytoplasmic membrane (Fig. 1c). Flagella were absent, but pili approximately $5 \mathrm{~nm}$ in width and up to $2 \mu \mathrm{m}$ in length could be detected infrequently.

\section{Utilizable carbon and nitrogen sources}

Strain LC $2^{\mathrm{T}}$ grew only on methane or methanol (10$50 \mathrm{mM}$ ). No other carbon substrates were utilized. Of the different nitrogen sources checked, it utilized nitrate, L-glutamine, L-glutamic acid, L-asparagine and L-aspartic acid. Growth on organic nitrogen sources such as peptone and yeast extract was better and faster than growth on nitrate. Strain LC $2^{\mathrm{T}}$ grew without any bound nitrogen source under standard gas conditions. The acetylene reduction test was positive, although the ethylene peak was very small and the reaction required overnight incubation.

\section{Effect of $\mathrm{pH}$, temperature and $\mathrm{NaCl}$ concentration on growth}

Strain LC $2^{\mathrm{T}}$ grew at $\mathrm{pH} 5-9$ when no additional buffers were used, with the best growth at $\mathrm{pH} 6-8$. When the medium was buffered, growth was observed only around neutral $\mathrm{pH}$, which might be due to the sensitivity of the strain to high concentrations of organic compounds. Strain LC $2^{\mathrm{T}}$ grew in a temperature range of $16-30^{\circ} \mathrm{C}$, the optimum growth temperature being around $25^{\circ} \mathrm{C}$. The specific growth rates at 16,25 and $30^{\circ} \mathrm{C}$ were $0.0024,0.0041$ and $0.0065 \mathrm{~h}^{-1}$. Although growth was fast at $30^{\circ} \mathrm{C}$, growth declined after reaching an $\mathrm{OD}_{570}$ of around 0.15 , which
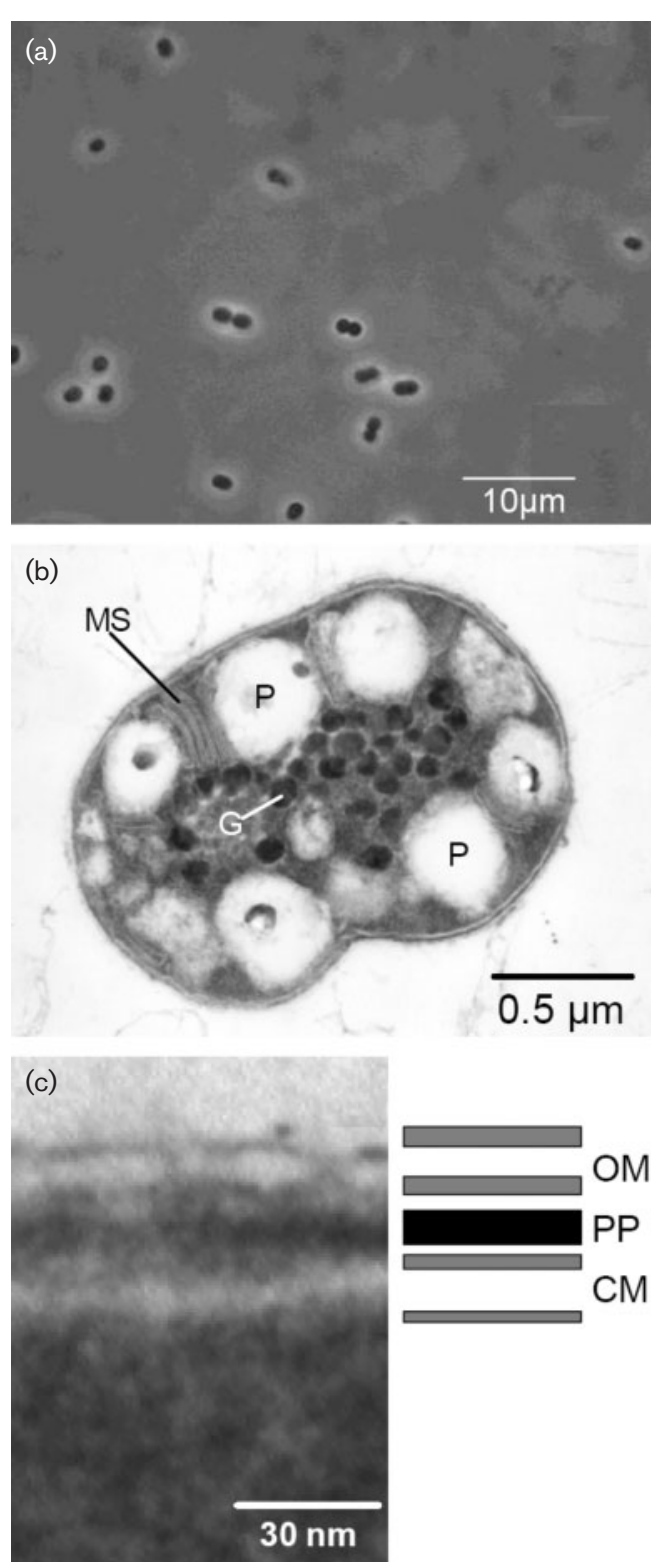

Fig. 1. Morphology of strain LC $2^{\top}$. (a) Phase-contrast micrograph of cells grown in liquid medium with methane. (b) Ultrathin sections showing membrane stacks (MS), polyhydroxyalkanoate $(P)$ granules and glycogen $(G)$ granules. (c) Ultrathin section of the cell periphery with the typical appearance of a Gram-negative cell envelope: two dark, thin layers of the outer membrane (OM), one dark, thick layer of peptidoglycan located in the periplasm (PP) and two dark layers of the cytoplasmic membrane (CM).

might be due to an imbalance of its metabolism. Little growth was observed at $10^{\circ} \mathrm{C}$, and no growth was observed at 37 or $4{ }^{\circ} \mathrm{C} . \mathrm{NaCl}$ added to the medium to concentrations of $0.5-2 \%$ inhibited growth. 


\section{Resistance to desiccation and heat and formation of exospores}

Strain LC $2^{\mathrm{T}}$ grew after a heat shock at 50 and $60^{\circ} \mathrm{C}$ for $10 \mathrm{~min}$, but did not grow after a heat shock at $70^{\circ} \mathrm{C}$. It formed neither microcolonies after exposure to $80^{\circ} \mathrm{C}$ nor exospores. Even though cysts were frequently observed in older cultures, they were not resistant to desiccation for 1 week.

\section{Cellular fatty acid analysis}

Strain LC $2^{\mathrm{T}}$ showed a pattern of fatty acids unique compared with representatives of the related type I methanotrophic genera Methylobacter, Methylosarcina, Methylomicrobium and Methylomonas, although the patterns of the genus Methylobacter were the closest (Table 2). Fatty acid patterns of Crenothrix polyspora were not available and thus could not be compared. The major fatty acid was $16: 1 \omega 7 c$. Strain LC $2^{\mathrm{T}}$ also contained $12: 0$ fatty acids, which have been observed only in the genus Methylosarcina. The proportions of $16: 1 \omega 7 c, 14: 0$ and $16: 0$ were comparable to those of members of the neighbouring genus Methylobacter. Strain LC $2^{\mathrm{T}}$ contained 15\% 16:1 $1 \omega 6 c$, which was similar to the values found in the genera Methylomicrobium and Methylomonas. There was no $16: 1 \omega 5 c$ or $5 t$ fatty acid, as seen in almost all other genera except Methylosarcina, which has a very low percentage of $16: 1 \omega 5 \mathrm{c}$. In addition, strain LC $2^{\mathrm{T}}$ also showed minor amounts of $15: 0,16: 1 \omega 11 c$ and $16: 03-\mathrm{OH}$ fatty acids, which have not been found so far in other type I methanotrophs.

\section{Absence of SMMO and presence of nitrogenase}

Strain LC $2^{\mathrm{T}}$ did not show the presence of sMMO as determined by PCR of mmoX genes or colorimetric assay. The presence of nitrogenase was confirmed by PCR amplification of a partial nifH gene. After NCBI BLAST, the partial sequence of around $300 \mathrm{nt}$ was found to be $90 \%$ similar to the nifH gene of an uncultured bacterium NR1620 (GenBank accession no. AF035504) and 86-88\% similar to partial nifH gene sequences of Methylobacter species, the closest being Methylobacter luteus ( $88 \%)$. The partial nifH gene sequence of Methylobacter tundripaludum SV $96^{\mathrm{T}}$ was $86 \%$ similar to that of strain LC $2^{\mathrm{T}}$.

\section{Phylogenetic analysis and $\mathbf{G}+\mathbf{C}$ content}

The complete $16 \mathrm{~S}$ rRNA gene sequence and partial pmoA gene sequence of strain $\mathrm{LC} 2^{\mathrm{T}}$ were determined in previous studies; the $16 \mathrm{~S}$ rRNA gene sequence was confirmed again after 1.5 years of cultivation, by cloning, screening of 20 clones by RFLP as described before (Bussmann et al., 2006) and sequencing of two clones. The sequences were $99.7 \%$ identical to the deposited sequence, with only two or three bases different, confirming the sequence and the stability of the culture under the present growth conditions. In the phylogenetic tree, the position of strain LC $2^{\mathrm{T}}$ was between the group of Methylobacter psychrophilus-like bacteria and C. polyspora (Stoecker et al., 2006) (Fig. 2). According to similarity values calculated using the ARB program (with or without $E$. coli as a filter), the closest cultured relatives are Methylobacter tundripaludum SV96 ${ }^{\mathrm{T}}$ (94\% similarity) and Methylobacter psychrophilus Z-0021 ${ }^{\mathrm{T}}$ (93.4\%). Different gene clusters of C. polyspora and other Methylobacter species showed similarity of $92-93 \%$. BLAST results revealed that the pmoA nucleotide sequence of strain LC $2^{\mathrm{T}}$ differed by $14 \%$ from the $p m o A$ sequences of Methylobacter sp. strain LW12 and Methylobacter sp. strain BB5.1 and by more than $15 \%$ from the other described species of Methylobacter. The amino acid similarities were $92 \%$ to Methylobacter sp. LW 12 and Methylomicrobium buryatense $5 \mathrm{~B}^{\mathrm{T}}$ and $93 \%$ to clone B67 and clone A55 from Lake Constance littoral sediment

Table 2. Cellular fatty acids of strain $L C 2^{\top}$ in comparison with other type I methanotrophs

Values are percentages of total fatty acids. Data for reference genera were taken from Bowman et al. (1995) (Methylomonas, Methylomicrobium, Methylococcus and Methylobacter) and Wise et al. (2001) (Methylosarcina). NR, Not reported; ND, not detectable.

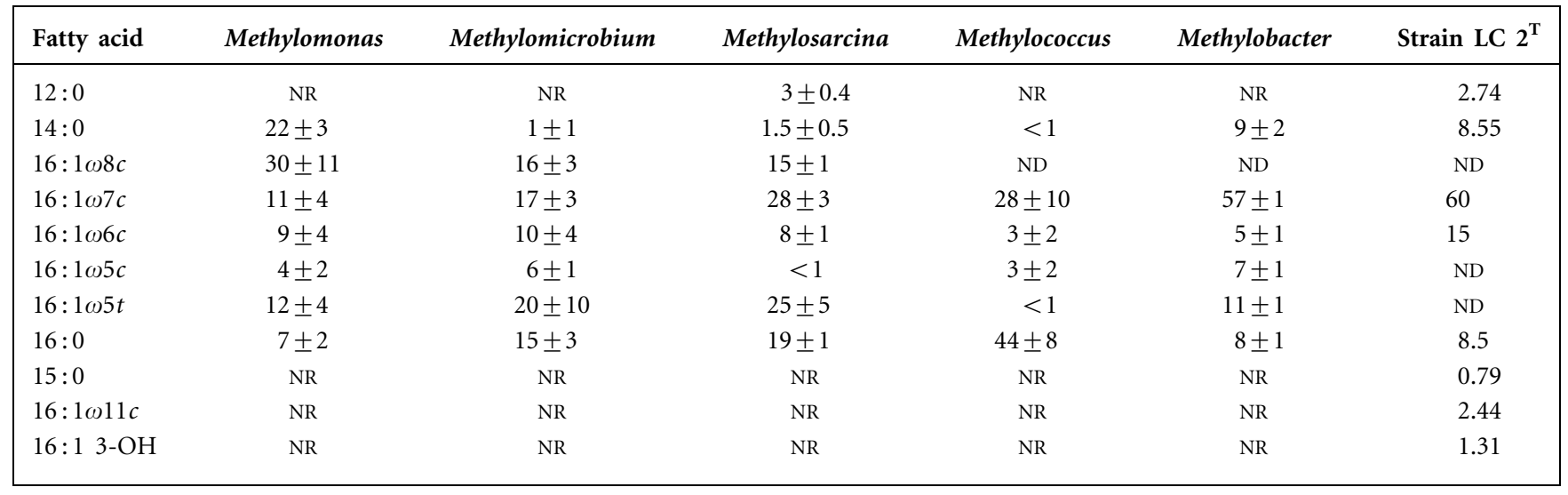




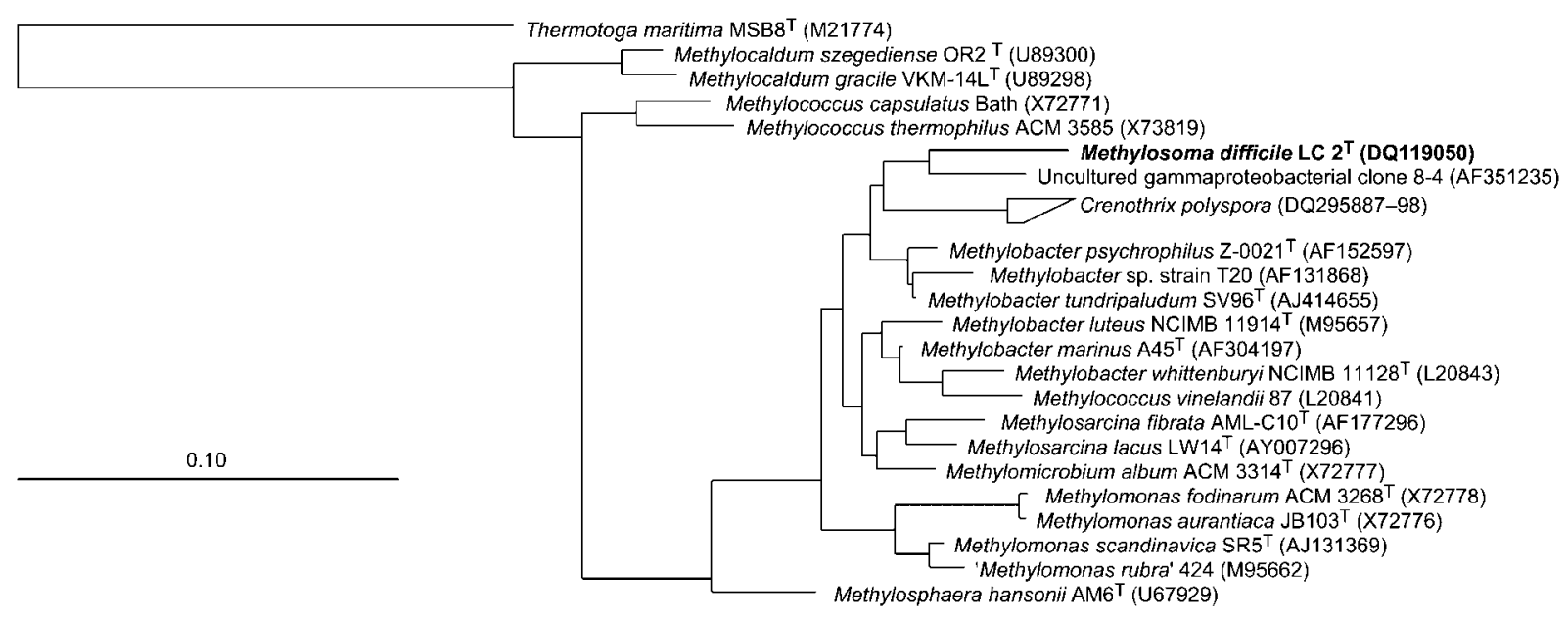

Fig. 2. Maximum-likelihood tree of the $16 \mathrm{~S}$ rRNA gene sequence of strain $L C 2^{\top}$ in comparison with other methanotrophic cultured members and clones. Strain numbers are indicated for species and GenBank accession numbers are given in parentheses. Bar, $10 \%$ sequence divergence.

(Bussmann et al., 2006). The unique position of the strain LC $2^{\mathrm{T}}$ sequence in the pmoA tree is shown in Fig. 3.

The $\mathrm{G}+\mathrm{C}$ content of strain $\mathrm{LC} 2^{\mathrm{T}}$ as determined by HPLC was $49.9 \mathrm{~mol} \%$. Comparison of strain LC $2^{\mathrm{T}}$ with other genera of methanotrophs is shown in Table 1. The sequence differences in the $16 \mathrm{~S}$ rRNA genes of strain $\mathrm{LC} 2^{\mathrm{T}}$ and species of Methylobacter with validly published names are between 6 and $8 \%$ and are therefore too large to allow strain LC $2^{\mathrm{T}}$ to be accommodated in the genus Methylobacter. Differences in $16 \mathrm{~S}$ rRNA gene sequences between $C$. polyspora and strain LC $2^{\mathrm{T}}$ are around $7 \%$. Beyond this, the morphological difference of filamentous versus non-filamentous growth prevents us from including our strain in the genus Crenothrix. Thus, strain LC $2^{\mathrm{T}}$ has to be described as a member of a new genus, Methylosoma, within the type I $\mathrm{MOB}$, as Methylosoma difficile gen. nov., sp. nov.

\section{Description of Methylosoma gen. nov.}

Methylosoma [Me.thy.lo.so'ma. N.Gr. prefix methylo referring to methyl groups; Gr. neut. n. soma body; N.L. neut. n. Methylosoma a methyl group (-utilizing) body].

Obligately aerobic, $\mathrm{C}_{1}$-compound-utilizing bacteria. Cells possess a typical membrane system with stacks of intracytoplasmic membranes, typical of type I methanotrophs. Gramnegative. Phylogenetic analysis and morphological characters place the genus close to the genus Methylobacter. The type and only known species is Methylosoma difficile.

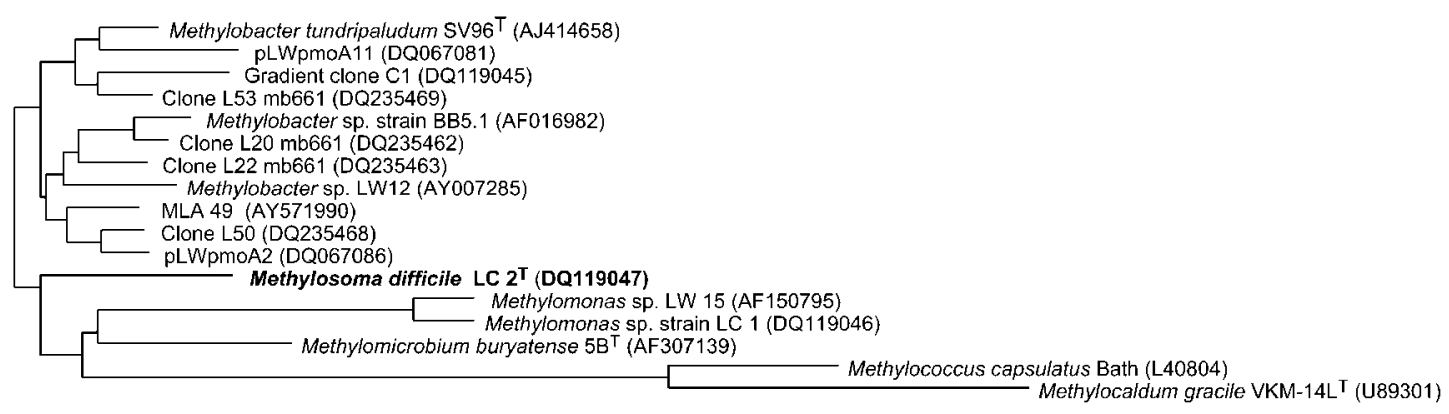

0.10

Fig. 3. Neighbour-joining tree based on the derived amino acid sequences of the $p m \circ A$ gene of strain $L C 2^{\top}$ and from other cultured and uncultured methanotrophs. Strain numbers are indicated for species and GenBank accession numbers are given in parentheses. Bar, $10 \%$ sequence divergence. 


\section{Description of Methylosoma difficile sp. nov.}

Methylosoma difficile (dif.fi.ci'le. L. neut. adj. difficile difficult, referring to difficulties in cultivating the type strain).

Large, coccoid cells, $1.5-2 \mu \mathrm{m}$ in length and approximately $1 \mu \mathrm{m}$ in diameter, often occurring in pairs, chains or aggregates; sometimes also slightly elongated rod-shaped forms. Non-motile; division by binary fission, forming cysts which are not resistant to heat or desiccation. Cells are palepink-pigmented and do not possess sMMO. Microaerobic, growing best at low ( $2 \%)$ oxygen tensions. Uses methane or methanol $(10-50 \mathrm{mM})$ as the sole carbon source and nitrate, L-glutamine, L-glutamic acid, L-asparagine or $\mathrm{L}$-aspartic acid as the nitrogen source. Fixes atmospheric nitrogen; nifH gene present. Grows best at $16-30{ }^{\circ} \mathrm{C}$ and at neutral $\mathrm{pH}$. Does not grow with enhanced concentrations of $\mathrm{NaCl}$ or copper. The major fatty acid is $16: 1 \omega 7 c$, followed by $16: 1 \omega 6 c, 14: 0$ and $16: 0 . \mathrm{G}+\mathrm{C}$ content of the DNA of the type strain is $49.9 \mathrm{~mol} \%$ (HPLC determination). Habitat: sediments of freshwater lakes, at the interface of oxic and methane-supplied sediment layers.

The type strain, $\mathrm{LC} 2^{\mathrm{T}}\left(=\mathrm{DSM} 18750^{\mathrm{T}}=\mathrm{JCM} 14076^{\mathrm{T}}\right)$, was isolated from littoral sediment of Lake Constance in May 2004.

\section{ACKNOWLEDGEMENTS}

This study was supported by Sonderforschungsbereich (SFB) 454 on the Deutsche Forschungsgemeinschaft, Bonn, and research funds of the Universität Konstanz. We wish to thank especially Dr Michael Hoppert, University of Göttingen, for performing the electron microscopic characterization.

\section{REFERENCES}

Altschul, S. F., Gish, W., Miller, W., Myers, E. W. \& Lipman, D. J. (1990). Basic local alignment search tool. J Mol Biol 215, 403-410.

Auman, A. J., Stolyar, S., Costello, A. M. \& Lidstrom, M. E. (2000). Molecular characterization of methanotrophic isolates from freshwater lake sediment. Appl Environ Microbiol 66, 5259-5266.

Auman, A., Speake, C. C. \& Lidstrom, M. E. (2001). nifH sequences and nitrogen fixation in Type I and Type II methanotrophs. Appl Environ Microbiol 67, 4009-4016.

Bodelier, P. L. E., Meima-Franke, M., Zwart, G. \& Laanbroek, H. J. (2005). New DGGE strategies for the analyses of methanotrophic microbial communities using different combinations of existing $16 \mathrm{~S}$ rRNA-based primers. FEMS Microbiol Ecol 52, 163-174.

Bowman, J. P., Sly, L. I., Nichols, P. D. \& Hayward, A. C. (1993). Revised taxonomy of the methanotrophs: description of Methylobacter gen. nov., emendation of Methylococcus, validation of Methylosinus and Methylocystis species, and a proposal that the family Methylococcaceae includes only the group I methanotrophs. Int J Syst Bacteriol 43, 735-753.

Bowman, J. P., Sly, L. I. \& Stackebrandt, E. (1995). The phylogenetic position of the family Methylococcaceae. Int $J$ Syst Bacteriol 45, $182-185$
Bussmann, I., Pester, M., Brune, A. \& Schink, B. (2004). Preferential cultivation of type II methanotrophic bacteria from littoral sediments (Lake Constance). FEMS Microbiol Ecol 47, 179-189.

Bussmann, I., Rahalkar, M. \& Schink, B. (2006). Cultivation of methanotrophic bacteria in opposing gradients of methane and oxygen. FEMS Microbiol Ecol 56, 331-344.

Costello, A. M. \& Lidstrom, M. E. (1999). Molecular characterization of functional and phylogenetic genes from natural populations of methanotrophs in lake sediments. Appl Environ Microbiol 65, 5066-5074.

Dedysh, S. N., Knief, C. \& Dunfield, P. F. (2005). Methylocella species are facultatively methanotrophic. J Bacteriol 187, 4665-4670.

Eller, G., Deines, P., Grey, J., Richnow, H.-H. \& Krüger, M. (2005). Methane cycling in lake sediments and its influence on chironomid larval $\delta^{13}$ C. FEMS Microbiol Ecol 54, 339-350.

Graham, D. W., Korich, D. G., Leblanc, R. P., Sinclair, N. A. \& Arnold, R. G. (1992). Applications of a colorimetric plate assay for soluble methane monooxygenase activity. Appl Environ Microbiol 58, 2231-2236.

Holmes, A. J., Owens, N. J. P. \& Murrell, J. C. (1995). Detection of novel marine methanotrophs using phylogenetic and functional gene probes after methane enrichment. Microbiology 141, 1947-1955.

Hoppert, M. \& Holzenburg, A. (1998). Electron Microscopy in Microbiology. Oxford: BIOS Scientific.

Lin, J.-L., Joye, S. B., Scholten, J. C. M., Schäfer, H., McDonald, I. R. \& Murrell, J. C. (2005). Analysis of methane monooxygenase genes in Mono Lake suggests that increased methane oxidation activity may correlate with a change in methanotroph community structure. Appl Environ Microbiol 71, 6458-6462.

Ludwig, W., Strunk, O., Westram, R., Richter, L., Meier, H., Yadhukumar, Buchner, A., Lai, T., Steppi, S. \& other authors (2004). ARB: a software environment for sequence data. Nucleic Acids Res 32, 1363-1371.

McDonald, I. R., Smith, K. \& Lidstrom, M. E. (2005). Methanotrophic populations in estuarine sediment from Newport Bay, California. FEMS Microbiol Lett 250, 287-293.

Mesbah, M., Premachandran, U. \& Whitman, W. B. (1989). Precise measurement of the $\mathrm{G}+\mathrm{C}$ content of deoxyribonucleic acid by highperformance liquid chromatography. Int J Syst Bacteriol 39, 159-167.

Nercessian, O. G., Noyes, E., Kaluyzhnaya, M. G., Lidstrom, M. E. \& Chistoserdova, L. (2005). Bacterial populations active in metabolism of $\mathrm{C} 1$ compounds in the sediment of Lake Washington, a freshwater lake. Appl Environ Microbiol 71, 6885-6899.

Pester, M., Friedrich, M. W., Schink, B. \& Brune, A. (2004). pmoAbased analysis of methanotrophs in a littoral lake sediment reveals a diverse and stable community in a dynamic environment. Appl Environ Microbiol 70, 3138-3142.

Poly, F., Monrozier, L. J. \& Bally, R. (2001). Improvement in the RFLP procedure for studying the diversity of nifH genes in communities of nitrogen fixers in soil. Res Microbiol 152, 95-103.

Roth, J., Bendayan, M., Carlemalm, E., Villiger, W. \& Garavito, M. (1981). Enhancement of structural preservation and immunocytochemical staining in low temperature embedded pancreatic tissue. J Histochem Cytochem 29, 663-671.

Stoecker, K., Bendinger, B., Schoning, B., Nielsen, P. H., Nielsen, J. L., Baranyi, C., Toenshoff, E. R., Daims, H. \& Wagner, M. (2006). Cohn's Crenothrix is a filamentous methane oxidizer with an unusual methane monooxygenase. Proc Natl Acad Sci U S A 103, 2363-2367.

Tamaoka, J. \& Komagata, K. (1984). Determination of DNA base composition by reversed-phase high-performance liquid chromatography. FEMS Microbiol Lett 25, 125-128.

Tourova, T. P., Omel'chenko, M. V., Fegeding, K. V. \& Vasiléva, L. V. (1999). The phylogenetic position of Methylobacter psychrophilus 
sp. nov. Microbiology (English translation of Mikrobiologiia) 68, 568-570.

Vela, G. R. \& Wyss, O. (1964). Improved stain for visualization of Azotobacter encystment. J Bacteriol 87, 476-477.

Wartiainen, I., Hestnes, A. G., McDonald, I. R. \& Svenning, M. M. (2006). Methylobacter tundripaludum sp. nov., a methane-oxidizing bacterium from Arctic wetland soil on the Svalbard islands, Norway $\left(78^{\circ} \mathrm{N}\right)$. Int J Syst Evol Microbiol 56, 109-113.

Whittenbury, R., Phillips, K. C. \& Wilkinson, J. F. (1970). Enrichment, isolation and some properties of methane-utilizing bacteria. J Gen Microbiol 61, 205-218.
Widdel, F. (1988). Microbiology and ecology of sulfate- and sulfurreducing bacteria. In Biology of Anaerobic Microorganisms, pp. 469585. Edited by A. J. Zehnder. Chichester: Wiley.

Widdel, F. \& Pfennig, N. (1981). Studies on dissimilatory sulfatereducing bacteria that decompose fatty acids. I. Isolation of a new sulfate-reducer enriched with acetate from saline environments. Description of Desulfobacter postgatei gen. nov. sp. nov. Arch Microbiol 129, 395-400.

Wise, M. G., McArthur, J. \& Shimkets, L. J. (2001). Methylosarcina fibrata gen. nov., sp. nov. and Methylosarcina quisquiliarum sp. nov., novel type I methanotrophs. Int J Syst Evol Microbiol 51, 611-621. 